\title{
Hubungan Budaya Dan Gereja Dalam Memberikan Pendidikan Bagi Anak
}

\author{
Irma Frans Kosi
}

\begin{abstract}
Abstrak:
Budaya dan gereja merupakan satu bagian yang terpenting dimana segala sesuatu yang menjadi pengajaran sebagai seorang pengajar seringkali membawa budaya-budaya yang tidak sesuai dengan kebenaran yang diajarkan didalam gereja dan akan membawa pengaruh bagi generasi penerus sebagai seorang yang akan meniru apa yang dilihat dan bahkan diajarkan dan akan menjadi turun temurun dalam hubungan budaya dan gereja dalam mengajarkan pendidikan bagi anak selaku penerus gereja.
\end{abstract}

\section{A. Pendahuluan}

Budaya dan gereja tidak dapat dipungkiri bahwa memiliki satu kaitan satu sama lain terlihat jelas dimana gereja ini merupakan suatu tempat untuk umat Kristen dalam melakukan berbagi jenis kegiatan-kegiatan yang berkaitan langsung dengan ibadah. Hal ini berarti bahwa gereja ini dapat berguna ketika ada orang atau manusia yang beraktivitas didalamnya dan juga merupakan tidak lepas dari budaya. Budaya inilah yang memiliki kaitan satu sama lain. Dapat dilihat dengan jelas bahwa kebiasaan-kebiasaan yang dilakukan oleh manusia didalam gereja dan tentu akan diteruskan kepada keturunan selanjutnya untuk itu gereja dan budaya tidak dapat terlepas satu sama lain karena dari hal inilah fungsi dari gereja ini dan yang akan mengelolah gereja tersebut. Pendidikan dalam gereja tentu akan terbawa oleh budaya atau kebiasaan-kebiasaan manusia dalam mengajarkan atau mendidik anak-anak yang akan menjadi penerus dalam suatu gereja. Melihat dari segi kedua hal ini yaitu budaya dan gereja maka ada kaitan satu sama lain yang tak dapat terpisahkan. Kaitannya disini ialah budaya adalah kebiasan manusia yang diturunkan kepada penerus selanjutnya dan tentu didalam gereja menjadi bagian penting bahwa setiap kebiasan-kebiasan yang terjadi dalam gereja pasti akan menurun kepada penerus selanjutnya dimana mereka akan mencontoh bahkan mengingat akan hal tersebut dan tentu akan diwariskan kembali kepada generasi selanjutnya. Kadangkala pendidikan yang dilakukan dari turun temurun banyak yang mengalami perubahan dan tentu juga ada yang masih menetap didalam suatu gereja. Karena dapat dilihat seiring berjalannya waktu perubahan pola pikir 
manusia yang semakin berkembang hingga menyebar luas kepada bagian-bagian pendidikan dalam gereja, pendidikan-pendidikan yang diturunkan ialah baik itu ajaran-ajaran kepercayaan bahkan kebiasaan-kebiasaan yang dilakukan dalam sebuah ibadah. Namun kadangkala tanpa disadari pengajaran-pengajaran yang dilakukan oleh orang yang sebagai pendidik yang telah turun temurun namun kenyataan bahwa ajaran-ajaran yang diberikan ternyata keliru bahkan adakalahnya yang terjadi ialah salah besar atau doktrin yang diajarkan salah bahkan telah diajarkan dari turun temurun hal inilah yang membawa kekeliruan dalam gereja akibat dari budaya. Perlu memperhatikan bahwa budaya-budaya yang telah menetap inilah yang harus diperbaharui dalam gereja. Oleh sebab itu perlu tindakan-tindakan dalam mendidik sesuai dengan kebenaran agar yang terjadi bahwa kebudayaan yang telah tetap atau mendarah daging dalam suatu gereja sesuai dengan kenyataan dan tidak terpaku pada hal-hal yang tidak ada kebenarannya. Oleh sebab itu tindakan manusia dalam gereja sangat diperlukan dimana tentu akan membawa akibat ketika hal-hal yang telah ditanamkan ternyata keliru atau bahkan salah dan menjadi suatu kebiasaan. Kedua hal ini yaitu Budaya dan gereja tidak dapat terpisahkan bahkan memiliki hubungan bahkan dalam mendidik anak-anak. Budaya dan Gereja merupakan memiliki kaitan satu sama lain dimana kebiasaan-kebiasaan yang dilakukan dalam gereja sebagaimana yang berfungsi sebagai tempat melakukan berbagai jenis aktivas dalam mendidik selaku tenaga pendidik dalam gereja tentu banyak yang diajarkan kepada anak yang telah diturunkan kepadanya sebelumnya dan yang kemudian diwariskan kembali kepada penerus selanjutnya.

\section{B. Tujuan dan Manfaat}

Adapun tujuan dari pemaparan diatas yaitu memahami hubungan antara Budaya dan Gereja yang memiliki satu kesatuan yang utuh dengan dilandasi kebenaran yang sesungguhnya dalam mendidik anak-anak sebagai bagian dari penerus dalam gereja.

Adapun manfaatnya ialah membantu setiap orang untuk memahami makna sesungguhnya dalam mengajarkan atau mendidik anak-anak sesuai dengan budaya yang berkembang dalam gereja dengan dilandasi oleh kebenaran yang sesungguhnya sebagai bagian dalam hubungan budaya dengan gereja. 


\section{Pembahasan}

Pendidikan bagi orang-orang yang menjadi penerus bangsa tidak luput dari pendidikan dalam gereja bahkan tak bisa terlepas dari budaya-budaya yang berkembang didalam gereja. Budaya dan gereja dalam hubungannya untuk mendidik penerus dalam gereja tentu ada keinginan untuk mendidik sesuai dengan kebenaran yang ada dalam pendidikan yang ajarkan kepada penerus gereja atau keturunan selanjutnya. Karakter dan kepribadian yang dibentuk melalui katalisasi minat dan antusiasme merupakan modal yang besar untuk mencapai/memeroleh sesuatu. Dengan minat seseorang akan memperhatikan sesuatu objek belajar dengan mencurahkan sepenuhpenuhnya kesadaran, tenaga, waktu, peluang dan fasilitas yang dimilikinya demi mendalami objek belajarnya. ${ }^{1}$ Dalam gereja manusia sebagai seorang tenaga pendidik tentu orang-orang yang menjadi penerus adalah orang-orang yang penasaran dalam gereja bagaimana yang terjadi dalam gereja ada rasa penasaran yang ingin didapatkan dengan demikian maka ada daya tarik sendiri baik itu sebagai seorang yang akan mengajar atau mendidik atau sebagai seorang yang akan menerima pengajaran tersebut. Ketika seseorang yang dalam proses mengajar tentu akan terbawa oleh sebuah budaya-budaya sebelumnya yang ia dapatkan dalam gereja. Intuisi seseorang memengaruhinya dalam membentuk orientasi terhadap sesama manusia dan akhirnya juga turut berperan dalam berbagai tindakan religius dan pertimbangan serta pengambilan keputusan etis. ${ }^{2}$ Dalam hubungan gereja dan budaya tentu akan membawa pengaruh kepada setiap orang yang akan menjadi bagian dalam didikan tersebut jadi ketika seseorang yang mengambil peran sebagai seorang tenaga pengajar dalam gereja oleh sebab itu pengaruhpengaruh budaya dalam gereja pasti akan terbawa-bawa sehingga dalam mengajar seseorang apalagi pada seorang anak yang merupakan daya tangkap yang kuat maka dari itu ketika dalam mengajarkan sesuatu perlu pemikiran-pemikiran yang panjang agar tidak menyesatkan atau melakukan suatu kesalahan didalamnya. Budaya modernisme dan globalisasi membawa berbagai kemudahan bagi umat manusia. ${ }^{3}$ Pengaruh dalam dari budaya-budaya yang ada dilingkungan sekitar tentu akan terbawah kedalam gereja atau memiliki hubungan dikarena budaya-budaya

\footnotetext{
${ }^{1}$ MENEMUKENALI KUNCI PENDIDIKAN IMAN BAGI ANAK DALAM KELUARGA DAN PEMBELAJARAN AGAMA DI SEKOLAH Rannu Sanderan Lembaga: STAKN Toraja, posel: rannusan@yahoo.com

2 I N T U I S I: Pendalaman Gagasan Hans-George Gadamer tentang Intuisi sebagai Supralogika Rannu Sanderan Institut Agama Kristen Negeri Toraja rannusan@gmail.com

${ }^{3}$ DISIPLIN ASKETISME DAN HARMONI KONTRIBUSI DISIPLIN DIRI BAGI PENGEMBANGAN PENDIDIKAN KRISTEN Rannu Sanderan Lembaga: STAKN Toraja, posel: rannusan@gmail.com
} 
luar yang dibawah oleh manusia kedalam gereja dan terus berkembang dan tentu membawa pengaruh besar bagi setiap orang-orang yang mendengar dan bahkan melihat secara langsung hal ini berarti ada pengajaran yang terjadi baik itu secara langsung maupun tidak langsung dan yang kemudian orang-orang bahkan generasi mudah sebagai penerus akan mengikuti hal tersebut sehingga berarti ada pengaruh besar yang terjadi ketika budaya luar dibawah ke dalam gereja bahkan dilibatkan dalam kegiatan atau aktivitas-aktivitas gerejewi. Fakta adalah iman lebih dominan diperoleh (dipelajari) justru melalui budaya; dan secara konkrit lebih banyak melalui keteladanan dan interelasi individual. ${ }^{4}$ Seorang yang mengajarkan pendidikan Kristen secara khusus dalam lingkungan gereja orang-orang yang diajarkan tentu dipengaruhi dengan berbagai jenis atau bentuk dari budaya-budaya yang ia terima dari sang guru atau pengajar dalam gereja disisi lain juga orang yang diajarkan tentu akan menjadikan sang guru sebagai contoh untuk kehidupan yang dijalani dalam lingkungan gereja hingga sebagai seorang guru tentu menyadari bahwa akan dijadikan dasar atau contoh oleh sang murid karena dia yang mengajarkan segala sesuatu kepadanya.

\section{Kesimpulan dan saran}

Seorang pengajar dalam gereja tentu akan memahami dengan baik hubungan budaya dan gereja dalam mendidik orang-orang yang akan menjadi penerus dalam gereja maka dari itu pengajar akan tahu memilih apa yang menjadi bagian yang perlu diajarkan dengan yang harus ditinggalakan dalam warisan budaya-budaya turun temurun karena guru adalah orangorang yang menjadi contoh atau dasar bagi setiap orang yang ada didalam gereja.

Saran bagi setiap orang yang berkonstribusi atau memberi diri dalam mengajar penerus gereja haruslah memahami dengan baik hubungan budaya dan gereja agar tidak salah langkah dalam berbagai bentuk tindakan yang dilakukan oleh setiap orang.

\footnotetext{
${ }^{4}$ EXEMPLARY MENEMUKENALI KUNCI PENDIDIKAN IMAN BAGI ANAK DALAM KELUARGA DAN PEMBELAJARAN AGAMA DI SEKOLAH Rannu Sanderan Lembaga: STAKN Toraja, posel: rannusan@yahoo.com
} 